AN ANALYIS OF THE CONCEPT OF ONENESS FROM A SUFI PERSPECTIVE AS PRESENTED BY MUHAMMAD NAFIS ALBANJARI IN HIS TREATISE - AL-DURR AL-NAFIS

\author{
Dr. Muhammad Khairi Mahyuddin* \\ DOI: $10.29370 /$ siarj/issue2ar13 \\ Link: https://doi.org/10.29370/siarj/issue2ar13
}

\begin{abstract}
:
The teachings of Tasawuf have flourished in the Malay world due to the efforts from Malay scholars who studied in Makkah. Muhammad Nafis alBanjari is one of them. He wrote his treatise on tawhid in a small epistle known as al-durr al-nafis fi bayan wahid al-af al-wa al-asma' wa al-sifat wa al-dhat al-taqdis. His teaching of tawhid written in Malay Jawi script is embroidered with Sufi teachings. However, his teachings raise issues of controversial and misunderstood nature. One of the contentious issues his epistle is blamed for is regarding the promotion of pantheism having connotation of unity of being (wahdah al-wujud). The objective of this study is to reveal the misconception of tawhid embroidered in the Sufi teachings and the importance of understanding the correct concept of tawhid from the original sources of Islam. This paper employs a detailed historical and textual study. Despite various controversies, al-Banjari epistle is considered to be a valuable work from a historical point of view. His highly succinct explanation requires additional reference and commentaries for readers to acquire appropriate understanding. It is according considered necessary to study his epistle under the proper guidance from the learned shuyookh to conceive it correctly.
\end{abstract}

KEYWORDS: Al-Banjāri, Al-durr al-nafīs, Tawhīid, Sufi order

\title{
His Life:
}

Little is known about al-Banjārī's life except what he mentioned in his book, al-durr al-nafi ís fí bayān wāhid al-af ${ }^{c} \bar{a} l$-wa al-asmā' wa al-șifāt wa al-dhât al-taqdis (the valuable pearl in explaining the unity of actions, names, qualities and transcendental divine essence). Al-Banjāri stated at the end of his book that his real name is Muhammad Nafís b. Idrīs b. al-

\footnotetext{
* Senior Lecturer, Faculty of Leadership and Management, Universiti Sains Islam Malaysia. Email: muhdkhairi@usim.edu.my
} 
Husayn al-Banjārí. He was born around 1148H/1735M in Martapura, South Kalimantan, and belonged to the Banjār royal family. Based on his birth date, he is believed to be a contemporary to Muḥammad Arshād alBanjārí (1122-1227H / 1710-1812M) and ' Abd al-Șamad al-Falimbānī (1118-1203H / 1704-1789M). He lived during three of Banjar's Sultanates such as Sulțān Taḥlilullah XIV(1707-1745M), Sulțān Tamjïillah XV (1745-1778M) and Sultān Tahmídullah XVI (17781808M). ${ }^{1}$

Around $1210 \mathrm{H} / 1795 \mathrm{M}$ al-Banjāri returned to his hometown in South Kalimantan for an Islamic mission. He went to strategic places and villages, such as Bali, Sumabawa, and Kelua, to preach Islam. Al-Banjārī passed away in his own land but the exact date and place of death are uncertain. There are various views about his place of death. According to one report, he died in Sigam or Pulau Laut. Another view is that he died in Kusan, Kotabaru or Kelua or in Tungkaran Pleihari, which are located in South Kalimantan. ${ }^{2}$

\section{His Education:}

It is believed that al-Banjari received his early education in his homeland South Kalimantan and then pursued his religious study extensively in Makkah and Madinah. However, no historical record supports this statement. Al-Banjari studied scince of theology ( ${ }^{c} \mathrm{ilm}$ al-kalām) of the alAsh'ari's school, science of Islamic law ('ilm al-fiqh) from al-Shafi'i's School, and Sufism (al-tasawwuf) from al-Junayd's school. Al-Banjari followed al-Junayd's school because this school adheres to the doctrine of sobriety $(s a h w)$ rather than intoxication $(s a k r)$ or divinely ecstatic utterance (shatahâat). He then emphasized practicality to embark spiritually on several Sufi orders. The Sufi order or tariqah süfiyyah is derived from Arabic term meaning 'road', 'way', 'path'. It comes finally to mean a common life ( $m u^{c} \bar{a}$ shara) founded on a series of special rules in addition to the ordinary observance of Islam, to become an adept (faqir), the novice (murid) receives initiation ( bay $^{c}$ ah, talqin) before a hierarchy of witnesses $\left(\right.$ shaykh) ${ }^{3}$

He primarily practiced the recognized orders such as alQādiriyyah established by Shaykh ${ }^{\mathrm{c}}$ Abd al-Qādir al-Jilānī (471$561 \mathrm{H} / 1078-1166 \mathrm{M})$, al-Shattariyyah established by Shah ${ }^{\mathrm{c}} \mathrm{Abd}$ Allah alShattari (d.890H/1485M), al-Naqshabandiyyah founded by Shaykh Muhammad b. Muhammad Baha' al-Din (718-791H/1318-1389M), alKhalwatiyyah founded by Shaykh Sidi 'Abu ${ }^{\mathrm{c}} \mathrm{Abd}$ Allah Siraj al-Din ${ }^{c}$ Umar al-Ahji or ${ }^{c}$ Umar al-Khalwati $(\mathrm{d} .800 \mathrm{H} / 1397 \mathrm{M})$ and al- 
Sammāniyyah founded by Shaykh Muhammad b. ${ }^{\mathrm{c}}$ Abd al-Karim alMadani al-Shaf ${ }^{c} i$ al-Samman al-Qadiri al-Sufi (1130-1189H /1718$1776 \mathrm{M}) .{ }^{4}$ Out of all disciplines, al-Banjari was known as an expert in science of theology ( ${ }^{c} \mathrm{ilm}$ al-kalamm) and science of Sufism (al-tașawwu). Since he follows these schools of thought and Sufi orders he is still within the structure of ahl al-sunnah wa al-jamâa $\tilde{a}^{-c}$.

Although he affiliated into many Sufi orders, he maintained and followed the original teachings of the orders as taught by his masters. No sources have been found which make any claim that he intended to form a new order. Since he successfully embarked onto many Sufi orders and had very deep knowledge in Sufism, he was called as mawlānāal- ${ }^{c}$ allāmah al-fahhāmah al-murshid 'ilā taríq al-salāmah (our master of the outstanding knowledgeable spiritual teacher to a safety path) an appellation indicating his expertise and highly spiritual experiential achievement and knowledge in Sufism discipline by those who came after $\operatorname{him}^{5}$.

\section{Scholars Exerting Influence in al-Banjārī's thought:}

Al-Banjārī studied under several outstanding scholars whom he documented in al-durr al-nafís as shaykhunā (our master). Among the dominant masters that exerted impacts on al-Banjari's thought are; Shaykh ${ }^{c}$ Abd Allāh b. Hijāzi b. Ibrahīm al-Sharqawī al-Azhari (1150$1227 \mathrm{H} / 1737-1812 \mathrm{M}$ ). He was a Faqih (a learned) who graduated from al'Azhar University. Shaykh Muhammad b. ${ }^{\mathrm{C}}$ Abd al-Karim al-Madani alShāfi $\bar{i}$ al-Shahīr bi al-Sammān al-Qādirì al-Ṣūfī (1130-1189H /17181776M) and Shaykh Șiddiq b. ${ }^{c}$ Umar Khān al-Madani.

Beside them, al-Banjāri also learned from Shaykh ${ }^{\mathrm{c}}$ Abd Allāh b. Ibrahim al-Mïrghani. He was believed to be the same person as ${ }^{\mathrm{c}} \mathrm{Abd}$ Allāh b. Ibrahīm b. Hasan b. Muhammad Amīn b. ${ }^{\mathrm{c}} \mathrm{Ali}$ al-Mïrghani, Abū al-Siyādah, ${ }^{\mathrm{C} A f i ̄ f}$ al-Dīn al-Mahjūb (d.1193H/1779M). He who was born in Makkah and died in al-Țā'if and was an outstanding faqih from the School of al-Hanafí. He is called as al-mahju $\bar{u} b$ (veiled) due to his practice of 'uzlah'(self-isolation) in his house for 30 years. Shaykh 'Abd alRaḥmān b. ${ }^{\mathrm{c}} \mathrm{Abd}$ al- ${ }^{\mathrm{c}} \mathrm{Az} \overline{\mathrm{iz}}$ al-Maqhribi $\overline{\mathrm{i}}$ al- ${ }^{\mathrm{c}}$ Umari ${ }^{\overline{1}}$ was probably known as ${ }^{\mathrm{c}}$ Abd al-Rahmān b. ${ }^{\mathrm{c}} \mathrm{Abd}$ al- ${ }^{\mathrm{c}} \mathrm{Az} \bar{z} \mathrm{z}$ al-Maqhribī al-Tādili al-Madanī alMālikī āl-Sammān Ṭariquatan (d.1200H / 1786M ).

Shaykh Muhammad b. Aḥmad al-Jawhari., his full name was Muhammad b. Aḥmad b. Hasan b. 'Abd al-Karīm al-Khālidī, 'Abū alHādi al-Shahīr bi ibn al-Jawhari aw al-Jawhari al-Ṣaghír $(1151 \mathrm{H}-1215 \mathrm{H}$ /1738-1801M). He was an Egyptian scholar and a faqih (a learned) in the 
School of al-Shāficī. Shaykh Yūsuf Abū Dharrah al-Mișrī was a scholar, whom al-Banjāri attended in his scholarly lectures in Masjid al-Harām. Shaykh al-Malawi, his full name was Ahmad b. ${ }^{c}$ Abd al-Fattah b. Yūsuf b. ${ }^{c}$ Umar al-Majīīi al-Malawī, Shihāb al-Di்n Abū ${ }^{c}$ Abbas al-Qāhirí al-Azhari al-Baqhdādi al-Shāficī $(1088 \mathrm{H}-1171 \mathrm{H})$, and Shaykh al-Suhaymi who was also known as Aḥmad b. Muhammad Muwaffiq al-Dín ${ }^{\mathrm{c}}$ Ali $\bar{i}$ al-Suhaymí alHusayni al-Mișri al-Shāfi ${ }^{\bar{i}}$ (d.1178H).

Al-Falimbāni stated that Shaykh Șiddīq b. ${ }^{c}$ Umar Khān al-Madani and Shaykh ${ }^{\mathrm{c}} \mathrm{Abd}$ al-Rahmān b. ${ }^{\mathrm{c}} \mathrm{Abd}$ al- ${ }^{\mathrm{c}} \mathrm{Aziz}$ al-Maqribi, were both the disciples of Shaykh Muhammad b. ${ }^{\mathrm{c} A b d}$ al-Karim al-Madani al-Shāfi ${ }^{\mathrm{c}} \mathrm{i}$ alShahīr bi al-Sammān al-Qādirī al-Șūfīi in Madinah. ${ }^{6}$ (Abdul Samad n.d) . It can be assumed that all these scholars, Muhammad Nafīis, Muhammad Arshād and ${ }^{\mathrm{c}}$ Abd al-Șamad al-Falimbāni, studied under the same teacher, that is, Shaykh Muhammad b. ${ }^{\mathrm{c}}$ Abd al-Karim al-Madani al-Shāfi $\mathrm{i} i$, but at different times.

Under the principal traditional teaching of Sufism, it is impermissible for one to embark into many Sufi orders. In the case of alBanjāri, it is seen that his basic Sufi order is al-qādiriyyah as he mentioned clearly in his book that it is his Sufi order. He most probably learned this order with Shaykh Muhammad b. 'Abd al-Karim al- Madani al-Sammān as evidenced from the title "al-qādirî" attributed to him, which indicates that he also belonged to al-qādiriyyah order, besides al-sammāniyyah order. The other Sufi orders become his supplementary spiritual learning for the purpose of the al-tabarruk (divine blessing and benediction). However, al-sammāniyyah order exerted strong impact on his Sufi discourse due to his strong reliance on the thought of and spiritual connection to Shaykh Muhammad b. ${ }^{c}$ Abd al-Karim al-Madani alSammān and Shaykh Șiddiq b. ${ }^{c}$ Umar Khān al-Madani.

From a clear identification found in al-Banjārī's teachers, it can be said that most his teachers are Theologians, Sufis and Jurists from Makkah and Egypt. It can be assumed that al-Banjāri probably traveled to Egypt and learned with some Egyptian scholars or they might have come to Makkah and taught him in masjid al-ḥarām but no empirical facts can support this.

\section{His Works:}

As far as it can be ascertained, al-Banjārī wrote several works in MalayJawi script during his life. One of them was al-Durr al-Nafis fi Bayān Wāhidah al-Af āl-wa al 'Asmā' wa al-Sifāt wa Dhāt Dhāt al-Taqdì which he completed writing on the Wednesday night after 'Ishā', 27 
Muharram 1200H / 1785M. He also wrote other small treatises including majmü al-asrār (collection of the secrets), penjelasan huruf-huruf abjad dalam al-qur'ān (elucidation on the alphabets in al-qur'ān), ilmu haqiqat yang sebenar benar (science of the divine reality in the real sense), masalah orang yang di jadikan imam (problem on person becoming the leader in praying). ${ }^{7}$

Among all treatises, the most popular epistle is al-Durr al-Nafíis. It has been taught in Makkah and many Asian countries including Malaysia and Indonesia. This is proven from manuscripts copied by particular people's handwriting such as Maḥmūd b. Muḥammad Yūsuf Terengganu that he copied it on Tuesday night between the Maghrib and ' Ishā' period at 29 Safar 1255H / 14 May 1839M. Wan Kenci B. Tuan Haji ${ }^{c}$ Abd alGhafūr also finished copying at al-Jamād al-Awwal $11306 \mathrm{H} / 1888 \mathrm{M}{ }^{8}$

The major reason why al-Banjārí wrote al-durr al-nafís is a response to help his fellow folk who did not know Arabic language to learn taw hid from the Sufi perspective. ${ }^{9}$ His work in translating and transforming the significant thoughts from various Arabic Sufi literatures into Malay-Jawi scripts denotes his mastery and proficiency in both Arabic and Malay languages, and his translation skill. He thus had a commendable capability to understand the relevant important facts from Arabic texts and translate them into a comprehensible Malay language in accordance with the level of understanding of the Malay society at that time.

Al-durr al-nafis is a widely accepted book. It was reprinted many times in Makkah, Egypt, Malaysia and Indonesia. A number of scholars who worked to verify and edit the contents of al-durr al-nafis as a sound teaching of tawhid before it was printed are: Shaykh 'Ahmad b. Muhammad Zayn al-Fațānì (d. 1903 AD), Shaykh Dā'ūd b. Ismā'il Dā'ūd al-Fațāni, Shaykh 'Idrís b. Husayn al-Kelantani, Shaykh ${ }^{\mathrm{c}}$ Abd al-Raḥman Gudang al-Fatani, Shaykh ${ }^{c}$ Abd Allah b. Ibrāhịim al-Qāḍi Kedah, Shaykh 'Idrīis al-Marbāwi (d 1989M) and Shaykh Ilyāṣ Ya ${ }^{c}$ qūb al-Azhari. ${ }^{10}$ These figures are the recognizable Malay Scholars who are well-experienced in writing and teaching various sciences of Islamic religious knowledge in the Malay World.

\section{Literature Used by al-Banjārīi in al-Durr al-Naf $\overline{\dot{s}}$ :}

In al-durr al-nafi is, al-Banjārī refers to authentic Arabic literature in order to support his explanation. Among the reliable literature are: al-risālah alqushayriyyah by Abd al-Qāsim al-Qushayrī (376-465H/986-1072M),

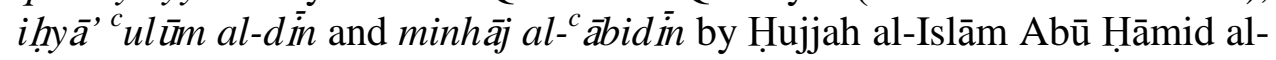


Ghazzāli al-Ṭūsí Shaykh Muḥammad b. Muhammad (450-505H/1058 $1111 \mathrm{M})$, fut ūḥ̂̄t al-makkiyyah and fușūṣ by al shaykh al-Akbar Muhy alDin Ibn 'Arabi (560-638H / 1165-1240M ), al-jawāhir wa al-durr and alyawāq ìt wa al-jawāhir fí bayān ${ }^{c}$ aqã id al-akābir by Shaykh Abd alWahhāb al-Sha ${ }^{c}$ rāni (898-973H/1493-1575M), al-hikam by Tāj al-Dīn Ibn 'Ațā'illāh al-Iskandari. (d.709H/1309M), sharh al-ḥadiṭ al-arba in li alnawāwi by Shihāb al-Dīn Ibn Hajar al- ${ }^{\mathrm{c}}$ Asqastalāni $(773-852 \mathrm{H} / 1372-$ 1449M), qhayth al-mawāhib al- ${ }^{c} \bar{a} l i y a h$ bi sharh al-ḥikam al- ${ }^{c}$ ațā'iyyah by Ibn ' ${ }^{c}$ Ubbād al-Randī, (733-792H/1333-1390M), Sharh al-Hikam by, Shihāb al-Dīn al-Ramli (773-844H/1371-1440M), dalāil al-khayrāt by Shaykh Muhammad b. Sulaymān al-Jazūlì al-Simlāli al-Shādhili ( 807$870 \mathrm{H} / 1404-1465 \mathrm{M}) .^{11}$

Additional scholarly treatises are: sharḥ fușūs al-hikam by Shaykh ${ }^{c}$ Abd al-Ghani al-Nābulusī (1050-1143H /1641-1731M), mulkhis mukhtașar tuḥah al-mursalah by Shaykh ${ }^{\mathrm{c}}$ Abd Allāh b. Ibrāhīm alMïrghani, sharḥ qașidah ${ }^{c}$ ayniyyah by Shaykh Șiddiq b. 'Umar Khān, sharh wird al- saḥar by Shaykh ${ }^{\mathrm{c}}$ Abd Allah b. Hijāzi b. Ibrāhīm al-Mișri, al-minḥah al muhamadiyyah, 'unwān al jalwah fi sha'n al-khulwah and ighāsah al-lahfān wa mu'ānasah al-wilhān by Shaykh Muhammad b. 'Abd al- Karìm al-Sammān al-Madani (1130-1189H/1718-1776M). From these primary sources, it is understood that al-Banjāri's exposition of al taw hid from the Sufi perspective is in line with the mainstream thinking of the $a h l$ al-sunnah wa jamâa ah school.

\section{Responses From The Contemporary Scholars:}

At the beginning of the $20^{\text {th }}$ Century, a number of scholars gave their responses to the teaching of tawhid in al-durr al-nafis. Some of them criticize it and some expressed a positive reaction. Wan Muhammad Shaghir reports that al-Sayyid ${ }^{\mathrm{c}}$ Alwi TTāhir al-Ḥaddād, a state Mufti of the Government of Johor, expressed his disapproval of the teaching of taw hid by al-Banjāri. The Mufti believed that the concept of tawhíd wujūdiyya in al-Banjāiri's book clearly conflicts to Islamic basic principles and mixes with Hinduism. Abdul Fatah Harūn also criticizes al-Banjārī in his books ahli sunnah dan wujudiyah -batiniah (mengenai ajaran salah)(ahl al sunnah and wujudiyyah-batiniyyah pertaining to its deviant teachings. He is of the opinion that al Banjāri's teaching of tawhìd wujūdiy is not in line with ahl Sunnah wa al-Jamăa $a$ hainstream thought and was influenced by Greek philosophy, Hinduism and Shi ism. Muhammad Hanif Hassan in his paper, sejarah ringkas perkembangan ajaran sesat di singapore (brief history of the development of deviant teaching in Singapore) remarks that 
al-Banjāri's teaching of tawhìd leans towards pantheism and the belief that God is a part of the world. ${ }^{12}$

Although al-Banjārī's teaching was severely criticized by many, his teaching also exerted a strong impact on many scholars such as ${ }^{\mathrm{c}} \mathrm{Abd}$ al-Rahman Siddiq Safat Tamabanhan Indragiri, a grandson of Shaykh Muhammad 'Arshād al-Banjārí. He wrote risālah ${ }^{c}$ amal ma $^{c}$ rifah (treatise for gnostic practice) in $1332 \mathrm{H}$ with a short quotation from the content of al-durr al-nafis. Furthermore, Shaykh Muḥammad Șālih b. ${ }^{\mathrm{c}}$ Abd Allah alMinangkabaw also wrote kashf al-asrār (revealing the secrets) in $1344 \mathrm{H}$ with reference to al-durr al-nafis. K.H Haderanie romanized al-Durr alNafis into the Indonesian language with some commentary entitled ilmu ketuhanan permata yang indah (al-durr al-nafís beserta soal jawab) (science of god the precious jewel with answer and question). Jahid Sidek also quoted the ideas of al-Banjāri in his book shaykh dalam ${ }^{c}$ ilm tariqah (shaykh in tariqah). ${ }^{13}$ It can be said that the difference in acceptance of alBanjāri's teachings of tawhid among the scholars can be a result of the the methods of interpretation they applied to receive them.

\section{The Concept of Taw hịd According to Al-Banjārī:}

In Ash'ari's school, the discussion method of unveiling and its relation to taw hid wuj $\bar{u} d \bar{i}$ is not vividly mentioned and discussed by the earlier theologians, but both concepts had been deliberated by the late theologians. Theologians in $\mathrm{Ash}^{\mathrm{c}}$ ari School had their own perception toward tawhìd wujūdi. Some of them like $\mathrm{Sa}^{\mathrm{c}}$ ad al-Din Mas ${ }^{\mathrm{c}} \overline{\mathrm{u}} \mathrm{d}$ alTaftāzāni (d.1390M) criticized severely tawhìd al-wujūdi through his theological methodology. He found out that the doctrine of tawhid wuj $\bar{u} d \bar{i}$ leans to pantheistic connotation and abrogating the shari $i^{\bar{i}}$ ah teaching. His view is based on his critical evaluation of the content in fuṣus al-hikam by Ibn ${ }^{\mathrm{c}} \mathrm{Arab} \overline{\mathrm{i}}$, ${ }^{\mathrm{c}} \mathrm{Ali}$ bin Muhammad (d.1240M). However the other theologian such as ${ }^{\mathrm{c}} \mathrm{Abd}$ al-Ghani al-Nābulusi $(\mathrm{d} .1731 \mathrm{M})$ defended taw hị al-wujūjd $\bar{i}$ as a true representation of the facts based on the relevant Sufi perspective. He harmonized between the theologian and Sufi methodology within the blueprint of shari $\bar{c} a h$ in a way that is not perceived by some a group of scholars to be against the theological principle and shari $\bar{i} a h$ practice. He wrote some books and commentary elucidating the true meaning of taw hid wujūd $\bar{i}$ and unveiling method such as $\bar{i}$ dah al-maqsūd fí bayān waḥdah alwujūd (clarifying what is meant by the unity of being) and his sharh fușus al-hikam (commentary of bezels of wisdom). ${ }^{14}$

As an adherent of Ash ${ }^{c}$ arí's school embroidered with Sufi teaching, al-Banjari is seen as expressing precise definition of tawhid in al-durr al- 
nafis in accordance with relevant sufi views. Al-Banjārí's exposition the concept of tawhid from the Süfi's perspective is more dominant than theological element and accordingly there is more emphases on the unveiling (kashf) methodology. This methodology can be considered as a doctrine of tawhìd for unveiling people (ahl al-mukāshifin). Tawhì literally means making one or asserting oneness. Al-Banjāri views it as believing wholeheartedly by direct vision and spiritual tasting in the oneness (wahdaniyyah, tawahhud) of Allah in all aspects of actions, names, attributes and essence. The ultimate essence of al-Banjāri's meaning of tawhid is the belief that there is no real being but Allah or there is no reality but the reality of Allah without any pantheistic meaning and strong practicing the shar $\bar{c} a h$ teaching internally as well externally.

In other words, this doctrine firmly asserts that Allah is the Absolute Real One Being and all other beings are metaphorical and nonexistence being without disregarding the shari ${ }^{i} a h$ principles. Thus, alBanjāri's teaching is in line with the doctrine of tawhid wujūdi or wahlah al-wujūd even though he never employs clearly this terminology in his writing. Waḥdah al-wujüd is the unity of being, a doctrine indicates that there is only Oneself which is manifested in multiplicity. Allah is the One in His essence, His qualities and His actions. There is only One Entity in existence and multiplicity appears through relation between non-essential entities. $^{15}$

Besides al-Banjari's teaching is considered to be inclined toward the wujudiyyah's doctrine, yet his teaching also can be categorized in other terminologies such as ${ }^{c} i l m$ al-mukāshafah (science of unveiling), ${ }^{c} i l m$ alasrär (science of the secrets), haq al-yaq in (absolute certainty), and fana' fi taw hid (annihilation in the unity) - It is considered as the highest degree of tawhid that he who attains it, his belief is affirmative and unchangeable. This is because this taw hid deals with the degree of certainty and unveiling of the reality of things in one's heart. It is similar with al-Ghazzali's teaching of tawhid. It means one ceases himself in the unification of God by witnessing nothing in being but Allah alone. This level is like oil in the kernel, the ultimate truth of tawhid. It is an article of faith of the truthful people (al-șiddiqūn wa al- ${ }^{c}$ àrifün). ${ }^{16}$

People who have experienced this kind of tawhid are people of unveiling. This is proven from the story of magicians who were fearless of the death punishment imposed by Fir ${ }^{c}$ aun because they believed firmly the reality of things discovered before their eyes and heart and that it is Allah who changed Mūsā's stick to be a big snake. The clear proof from unveiling the reality of things strongly refrain them from changing their belief as evident in the al Qur'ān. Allah says: So they (the Magicians) 
were defeated there and then and were returned disgraced. And the sorcerer fell down prostrate. They said: We believe in the Lord of all creatures. The Lord of Mūsa and Hārūn. Surely I (Fir ${ }^{c}$ aun) will cut off your hands and your feet on opposites sides than I will crucify you all. They said: Verily, we are returning to our Lord. And you take vengeance on us only because we believed in the Ayat (proofs, evidences, lessons, signs etc.) of our Lord when they reached us. Our Lord pour out us patience and cause us to die as Muslims. ${ }^{17}$ And the magicians said: "We prefer you not over the clear signs that have come to us and to Him (Allah) Who created us. So decree whatever you desire to decree for you can only decree regarding this life of the world.",18

This tawhid is also supported by the hadith in which the Prophet asked the proof from al-Hārithah b. Malīk al-Anșārī to testify to his belief. The Prophet questioned him one day: "How is your condition today, Oh alHārithah."? He replied: "I am a true believer". The Prophet asked him again: "Indeed for every single word has its own fact thus what is your testimony of your genuine faith."? He replied: "I have removed from myself looking into worldly life, so it's stone and it's gold is similar (valueless) to me, thus I was sleepless at night for worship and was thirsty in shrine day until I can watch like as my Lord's throne in front of my eyes obviously and like as I saw people in Paradise have mutual visits of each other in Paradise and like as I perceive the sound of screaming people in the fire". The Prophet said: "You are really knowable, so consistent in such condition". In another narration the Prophet said: "Who wish to see one whose Allah enshrines His Light into his soul, look forward to alHarithah b. Malik. ${ }^{19}$ From the account given, it can be said that alBanjāri's doctrine of tawhìd is so unique that requires a proper Sufi methodology to comprehend it.

\section{His Methodology in Taw hị :}

Al-Banjari adheres to the al-Asha ${ }^{c}$ ari's school in science of theology ( ${ }^{c}$ ilm al-kalām). He uses the Ashacari's speculative method that is reasoning as a starting point in learning tawhid and then ends up by employing Sufi's method: method of spiritual unveiling (kashf) and spiritual tasting (dhawq) Both are as direct vision or the uncovering of anything covered that alludes to a knowledge which does not require proof as it is a direct perception of the nature of thing ${ }^{20}$

Al-Banjāri combines both theological and Sufi's method as the integrated means to understand tawhid. However, the Sufi' method prevails in his teaching and writing. He believes that the unveiling (kashf) 
is a perfect way to verify the true sense of tawhid. It is so important to purify the heart because the heart is the basic locus of al-tawhid. Since the kashf phenomena can occur in the pure heart, it becomes the best mean to perceive the real meaning of tawhid. Thus, in Sufism it is important to know the characteristics of the heart because it is a basic in religion and fundamental way to reach Allah. ${ }^{21}$ Some people claim that the only way to purify the heart is by experiencing Sufi path through exercising any Sufi order's institution.

As the method of unveiling dominates in al-Banjāri's explanation, his method is considered within ahl al-sunnah wa al-jamäah's methodology but most people do not realize it. His method is in line with that of ${ }^{\mathrm{c}} \mathrm{Abd}$ al-Wahhāb b. ${ }^{\mathrm{c}} \mathrm{Ali}$ b. ${ }^{\mathrm{c}} \mathrm{Abd}$ al-Kāfī al-Subki, 'Abū Nașr Tāj alDin (727-771H / 1328-1370M), known as Ibn al-Subki in his exposition in "sharh caqidah Ibn al-Häib" where he stated," that, "Ahl al-Sunnah wa al-Jama $\bar{a}^{-c} a h$ unanimously agreed on one similar basic creed such as necessary (al-wäjib), possible (al-jäiz) and impossible (al-mustahịi $)$ to Allah even though they employed different methodology and principle to perceive theological issue. Ahl al-sunnah wa al-jamâa $a h$ are divided into three main group; The first is ahl al-Hadith (the traditionalist); their fundamental concept is based on literal interpretation of al-Qur'ān and alHadith and consensus agreement (al-ijma $\left.\bar{a}^{-c}\right)$, the second is ahl al-nazar wa $a l-{ }^{c} a q l$ from al-Ashấiriyyah and al-Mäturidiyyah group (the rationalist and demonstrationist); their basis is complementary with reason and revelation (al-Qur'ān and al-Hadith). The third is ahl al-wujd wa al-kashf (people of experience and unveiling) namely the Sufi group; Their starting points commence with the method of ahl al-nazar and ahl al-hadith and end up with the unveiling method (al-kashf) and Divine inspiration (alilhām), 22

Since al-Banjārī integrates both methods (theological and Sufi), he is seen as continuing Abd al-Wahhāb al-Sha rāní's approach in explaining the meaning of tawhìd. It is seen that Al-Sha ${ }^{c}$ rāni is the first scholar who claimed that he officially worked in harmonizing between reasoning and unveiling method in $a l^{c} a q i d a h$. Both actually are not contravened but have mutual role to strengthening each other. ${ }^{23}$ Al-Banjāri's way in explaining tawhid follows the steps of eminent Sufi scholars utilizing many terminologies, metaphors, allusions and symbols as indicators to present the meaning in tawhid. These ways are styles and trends of Sufi scholars to avoid people misinterpreting their teaching and accusing them of heresy. This tradition is also practiced by al-Hasan al-Bașri (d.110H/728M) and al-Junayd al-Baghdādi (d. 298H/910M). For instance, to avoid misinterpretation by people, al-Junayd never spoke publicly about 
tawhï from Sufi perspective to ordinary people. However if he wanted to discuss the issue of tawhid in this manner, he will close the door and keep the key secured. ${ }^{24}$

Al-Banjārī's methodology in attaining al-kashf (unveiling) is called mujähadah al-kashf (striving unveiling) because it deals with pure heart. For those who wish to realize this kind tawhid, they must follow its own particular discipline and understand its terminologies properly. If not, one is unable to perceive the highest end of the Sufis in their elaboration the meaning of tawhid. His way is clarified by Ibn ${ }^{\mathrm{c}}$ Ajibah, Ahmad b. Muhammad b. ${ }^{\mathrm{c}}$ Ajibah al-Hasani $(\mathrm{d} .1224 \mathrm{H})$. He stated that mujāhadah alkashf (striving unveiling) compulsorily requires a shaykh because, in fact, the shaykh has spiritual escalation (tarqiyyah) that can help improve pupil's spiritual dimension within their meeting, a particular spiritual ceremony, and explain unseen phenomena like the Prophet sought descriptions from Waraqah b. Nawfal to know about Prophethood's matter and its signs.

In this way, the shaykh is called shaykh al-tarqiyyah (master of spiritual escalation). He also covers the functions of shaykh al-taclim (master of learning) and shaykh al-tarbiyyah (master of teaching). Ibn ${ }^{\mathrm{c}}$ Ajibah acknowledged the necessity of the shaykh in mujāhadah al-kashf as very completely helpful to attain objective and close to the truth. Whereas in mujāhadah al-taqwā, it is seen as unnecessary to require the shaykh for guidance and it is sufficient for one to practice by collecting data via reading books. In mujāhadah al-istiqāmah (striving of consistency), it is encouraged to seek a shaykh for instruction on what the best matter for one is but sometimes it also enough for him to read in order to attain his end objective. However, both are recommendable and more helpful to have the Sufi master to complete one's aim. The scholars who practice mujāhadah al-kashf are the likes of al-Ghazzāli who learned from al-Shaykh Muhammad al-Bāzighānī, ${ }^{c} A b d$ al- Wahhab al- Sha rāní took a lesson from Shaykh ${ }^{\mathrm{c}}$ Ali al- Khawwaș, Shaykh ${ }^{\mathrm{c}} \mathrm{Izz}$ al-Din b. ${ }^{\mathrm{c}}$ Abd alSalām studied under Shaykh Abū al-Hassan al-Shāzili. ${ }^{25}$ (Ībn Ājībāh 2000; al-Sha ${ }^{c}$ rānì n.ḍ)

In conclusion, al-Banjārī's views on Sufism have a strong basis from al- Qur'ān and al-Sunnah and spiritual experiences of previous prominent Sufi Scholars. He chooses reason and the unveiling method to understanding tawhid. He never denies the function of reason in understanding the foundation of tawhid. The use of the unveiling method is the last step to verify the true meaning of tawhid. One who is able to comprehend the meaning of tawhid from a Sufi's perspective is called as al-rāsikhūn fi al- ${ }^{c} i l m$ (those who firmly established in knowledge). 


\section{Methodology of His Writing:}

Al-Banjāri has his own way in writing about the teaching of tawhid. Following the tradition of many scholars, he commences his preface by praising Allah and asking for the Prophet Muhammad blessings upon him as well as his families, companions, Saints and the followers of followers of the Prophetic teaching until to the Day of Judgment. This action is observed as a courtesy from al-Banjāri toward Allah and His Prophet. He regards his writing as a succinct work (risālah mukhtașarah) comprising a high-level teaching about taw hid cited from both the words of reputable Sufi's scholars as well as from authentic Sufis' texts.

As his work comprises a highly valuable teaching level of taw hid, he entitles his work as al-durr al-nafi . He also mentions his objective is to help his fellowmen who cannot understand the Arabic language to learn taw hid in a Malay medium. To indicate the element of tawhid in his work, he says that he composes the content of the book by requiring Allah's assistance and His guidance. ${ }^{26}$

He organizes his teaching systematically: by locating introduction, the four classifications of taw hid and a conclusion. In his introduction, alBanjāri explains the four major destructive qualities that prevent one from reaching knowledge of God such as laxity (futūr), lack of interest (malāl), hypocrisy (riyā'), dishonesty ( $\left.\operatorname{sum}^{c} a h\right)$, and self-satisfaction $\left({ }^{c} u j \bar{u} b\right)$. This introduction is pivotal for one to be aware about spiritual obstacles in traveling in the path to God. ${ }^{27}$ This shows al-Banjārí's expertise in successfully educating one in undergoing the spiritual journey to God.

He then explains the categorization of tawhid into four divisions systematically: tawhìd al-af âl (the unity of actions), tawhìid al-asmā' (the unity of names), tawhì al-sifät (the unity of attributes) and tawhìd al-dhät (the unity of Essence). The pattern of organizing topics and the divisions of tawhïd is similar to the way done by ${ }^{\mathrm{c}} \mathrm{Abd}$ al-Karim al-Jìli (d. $832 \mathrm{H} / 1428 \mathrm{M}$ ) in his book al-insān al-kāmil. ${ }^{28}$ But al-Banjārí's explanation is different from al-Jili in form of expression. He tries to make his work succinct and simple and includes various short significant citations of Sufi Scholars and stresses a greater commitment to Islamic law.

In each topic of tawhid, he elaborates the teaching with a brief definition and supports the explanation with al-Qur'ān and al-Hadith, and citations from various authentic Sufis literatures and clarifications from his masters' words. Besides referring to al-Hadith, he also alludes to the words of companions of the Prophet and reputable Saints. It is believed he uses the words of companions and saints to strengthen his elucidation and 
make it clearer. However, in citation of al-Hadith, al-Banjāri does not mention the source of al-Hadith, neither its narrator nor its value. It seems in his time that it is not so important to state names of the narrators because society at his period placed trust in the scholars' credibility and their teaching.

On another point, al-Banjāri does not use full translation in his work. On some occasions, he still maintains use of Arabic terminologies such as naskhah (transcript), ' adam (nonexistence), fan $\bar{a}$ ' (annihilation), baq $\vec{a}$ (continuance), wuj $\bar{u} d$ (being), ittiḥād (union), hulu $\bar{u}$ (incarnation) etc. It is believed that these terminologies do not necessarily need to be translated since they signify important meaning in their original form. If they are translated, they may lose the actual meaning because translation sometimes does not give accurate impressions unless in Arabic terms. Most of al-Banjāri's elucidation is short and precise so that it needs more elaboration from the original text.

In explaining the difficult idea of taw hịd, al-Banjāri uses symbolic expression and exemplification to make the idea understandable. In order to maintain ahl al-sunnah wa al jamã ah mainstream school of thought, alBanjāri does a comparative study between other schools of thought in order to clarify the belief in a balanced manner. As an adherent of al-

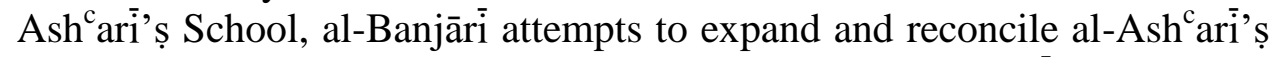
thought in Sufism. This is because almost all of al-Ash ${ }^{c}$ ari's thought is similar to Sufism even though they apply different terminologies but have a close meaning to each other. In his conclusion, he advises that his teaching should be kept properly to its members. He supports this idea by several Quranic verses and relevant al-Ḥadith.

\section{Conclusion:}

In nutshell, even al Banjari epistle faces many challenges and critique but it is still relevant and readable by many Malay scholars in the Malay world. It can be said that al-Banjārí's ș way of writing is well organized, precise and complicated in several sentences as well as terminologies. It is not suitable for all people but is more appropriate for those who seek to learn tawhid under the guidance and explanation of shaykh murshid. Even though, his explanation may be said to be too succinct, but it requires the additional reference and commentaries from other authentic books in theological and Sufism to understand the teaching of taw hid correctly to avoid misunderstood from its literal expression and teaching. 


\section{REFERENCES:}

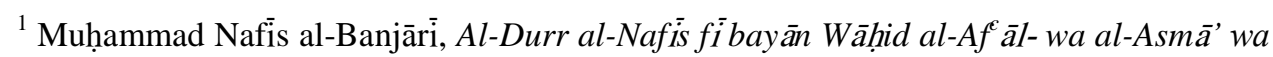
al-Ṣifāt wa al-Dhāt Dhāt al-Taqdìs,n.d. Dār Iḥyā' al-Kutub al- ${ }^{\mathrm{C}}$ Arabiyyah, Miṣr,.p. 2; Azyumardi Azra, The Transmission of Islamic Reformist to Indonesia: Networks of Middle Eastern and Malay-Indonesia 'Ulama' In the $17^{\text {th }}$ and $18^{\text {th }}$ Centuries. 1992, (P.hd. Dissertation, United Stated: Colombia University, 1992), p. 508. H.Ahmadi Isa, Ajaran Tasawuf Muhammad Nafis dalam Perbandingan 2001, SriGunting Jakarta,p.23.

2 Wan Muhammad Shaqir Abdullah, Penyebaran Islam Dan Silsilah Ulama Sejagat Dunia Melayu, 1999,vol.8, Khazanah Fathaniah, Kuala Lumpur p. 49.

${ }^{3}$ H.A.R Gib and J.H Kramers, Shorter Encyclopedia of Islam, 1973, Leidin E.J. Brill Netherland,p. 573.

${ }^{4}$ Muhammad Nafīis al-Banjārī, Al-Durr al-Nafís fí bayān Wāhid al-Af āl-wa al-Asmā̄' wa al-Şifāt wa al-Dhāt Dhāt al-Taqdìs,p.2-30

${ }^{5}$ Muhammad Nafīis al-Banjārí, Al-Durr al-Nafís p.1

${ }^{6}$ c Abd al- Samad al-Falimbangi, Sayr al-Sālikín,vol.3 n.d,Maktabah wa Matba ${ }^{\mathrm{c} a h}$ Muhammad al-Nahdī wa Aulādah: Thailand, p. 179.

${ }^{7}$ Wan Muhammad Shaqir Abdullah, Penyebaran Islam Dan Silsilah Ulama Sejagat Dunia Melayu,vol.8.p.53

${ }^{8}$ Kataloq Manuskrip Melayu, Koleksi Perpustakaan Negara Malaysia, MSS 2488(A) alDurr al-Nafīs, 2001, Perpustakaan Negara Malaysia, Kuala Lumpur p. 63.

${ }^{9}$ Muhammad Nafis al-Banjāri, Al-Durr al-Nafís, p.2.

${ }^{10}$ Wan Muhammad Shaqir Abdullah, Penyebaran Islam Dan Silsilah Ulama Sejagat Dunia Melayu,vol.8.p.53

11 Muhammad Nafis al-Banjārī, Al-Durr al-Nafīs, p.2-30;Ismā̄il Bāshā al-Baghdādī, Hidāyah al- ${ }^{c} \bar{A}$ rifïn, vol.5, n.d, Mu'assasah al-Tārikh al- ${ }^{c}$ Arabī Bayrūt p. 117; Bassām, ${ }^{c}$ Abd al-Wahhāb al- Jābi, d mucjam al-Aclam Mucjam Tarajum li Ashhur al-Rijal wa alNisa' min al- ${ }^{\mathrm{c}} \mathrm{Arab}$ wa al-Musta ${ }^{c}$ ribin wa al-Mustashriqin,Al-Jaffan al-Jabi, Cyprus:.p. 430; Al-Ziriklì, Khayr al-Dīn al-A 'lām Qāmus Tarajum li Ashur al Rijāl wa al-Nisā' min al- ${ }^{\mathrm{c}}$ Arab wa al-Musta ${ }^{\mathrm{c}}$ ribīn wa al-Mustashriqīn,vol.4, Dar al- ${ }^{\mathrm{C}} \mathrm{Ilm}$ li al- Malayīn, Bayrut:.p 22.

12 Abdullah Muhammad Zain, Haji Mohammad Alwi Yusoff and Muhammad Haizuan Rozali Kebatilan Dalam Ajaran Kebatinan 2003, KUIM,Kuala Lumpur, p.152.

${ }^{13}$ H.Ahmadi Isa, Ajaran Tasawuf Muhammad Nafis dalam Perbandingan,p.42; K.H Haderanie, Ilmu Ketuhanan Permata yang Indah (al-Durr al-Nafis beserta soal jawab) C.V. Nur Ilmu Surabaya,p.1; Jahid Sidek, Shaykh dalam ${ }^{c}$ ilm Tariqah, 1997, Universiti Malaya, Kuala Lumpur p. 243.

14 Al-Nābulūsī, 'A Abd Al-Ghani Ị̣̄ah Al-Maqsūd Fī Bayān Waḥdah Al-Wujūd wa Ma ahu Masā'il fi al Tawhīd wa-al-Tasawwuf, 2004..Edited Sa ${ }^{c} \bar{i} d{ }^{c} A b d$ al-Fattah. Dār Āfāq al'Arabiyyah Al-Qāhirah,p.3.Risālah fī waḥdah al-wujūd li $\mathrm{Sa}^{\mathrm{c}}$ ad al-Dīn al-Taftāzanī. https://archive.org/stream/WahdaAlwgwwd\#page/n1/mode/2up.p.2

15 Aisha Bewley, A Glossary of Islamic Term, 1998, Deluxe Printer, London. p. 227.

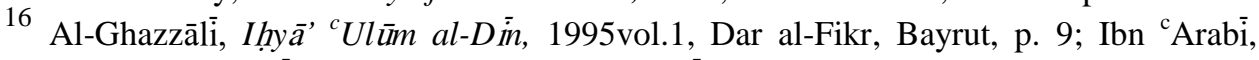
Muhammad ibn ${ }^{\mathrm{c}}$ Alī. Al-Futūhāat al-Makkiyyah fī Ma rifah al-Asrār al-Mālikiyyah wa alMulkiyyah,vol.1, ,n.d. Dār Ihyyā' al-Turath al- 'Arabī, Bayrūt, p.69.

${ }^{17}$ Al-Quran al-A ${ }^{\mathrm{c}}$ rāf 7:119-126.)

18 al-Quran. Țāha 20: 72

19 al-Tibrāni. al-Mu ${ }^{\mathrm{c} j a m}$ al-Kabīr.n.d, Dār al-Bayān Al- ${ }^{\mathrm{c}}$ Arabī,Jeddah. 
${ }^{20}$ Aisha Bewley, A Glossary of Islamic Term, p. 213

${ }^{21}$ Al-Ghazzāli, Ihyya ${ }^{, c}$ Ulūm al-Dìn, vol.3, p.3.

22 Al-Zubaydi, Muhammad b. Muhammad, Itḥâf al-Sādat al-Muttaqī bi sharh Ihyyā' ${ }^{c}$ Ulüm al-Dīn, vol.2, 1989,Dār al-Kutub al-'Ilmiyyah,, Bayrūt,p. 9

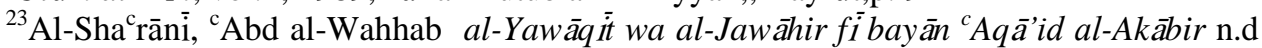
Dār Ihyā' al-Turāṭh al- ${ }^{\mathrm{c}}$ Arabī, Bayrūt,p.15.

${ }^{24}$ Al-Sha ${ }^{\mathrm{c}}$ rani, ${ }^{\mathrm{c}} \mathrm{Abd}$ al-Wahhab, Ibid.p. 18.

${ }^{25}$ Ibn ${ }^{\mathrm{c}}$ Ajībah, Aḥmad b. Muḥammad, al-Futūḥāt al-Ilāhiyyah fī sharh al-Mabāḥith alAṣliyyah 2000, Dār al-Kutub al- ${ }^{\mathrm{C} I l m i y y a h, B a y r u ̄ t: p .75 ; ~ a l-S h a ~}{ }^{\mathrm{c}}$ rānī, ${ }^{\mathrm{c}}$ Abd al-Wahhāb, Lațäif al-Minan wa al-Akhlāq fí wujūb al-Taḥadduth bi ni ${ }^{c}$ mah Allah ${ }^{c}$ ala al-Iṭlāq n.d $\bar{A}^{\mathrm{A}}$ lam al-Fikr, Bayrūt.,p 87.

${ }^{26}$ Muhammad Nafis al-Banjāīi, al-Durr al-Nafïs, p.2.

${ }^{27}$ Muhammad Nafis al-Banjāri, al-Durr al-Nafis, p.3.

${ }^{28}$ Al-Jīili, ${ }^{\mathrm{c}} \mathrm{Abd}$ al-Karīm b. Ibrāhim, al-Insān al-Kāmil fí ma ${ }^{c}$ rifat al-Awākhir wa al-Awāil ,2005,Dār al-Kutub al- ${ }^{\mathrm{I}}$ Ilmiyyah ,Bayrūt, p. 87-102 